Review Article

\title{
The use of cyclooxygenase- 2 inhibitors in depression: a narrative review of the state of evidence
}

\author{
Alisha Abbas, Narendra Kumar*, Reshma Choudhary
}

\author{
Department of Pharmacology, \\ King George Medical \\ University, Lucknow, Uttar \\ Pradesh, India
}

Received: 07 August 2019 Accepted: 10 September 2019

\section{*Correspondence to: \\ Dr. Narendra Kumar, Email: narenkgmu@gmail.com}

Copyright: (C) the author(s), publisher and licensee Medip Academy. This is an openaccess article distributed under the terms of the Creative Commons Attribution NonCommercial License, which permits unrestricted noncommercial use, distribution, and reproduction in any medium, provided the original work is properly cited.

\begin{abstract}
Multiple lines of evidence suggest that inflammation contribute to the pathophysiology of depression. Various studies have found that patients with major depression have higher levels of pro-inflammatory cytokines like interleukin-1, interleukin-6, tumor necrosis factor-alpha and C-reactive protein. As a consequence of above findings this narrative literature review was done to look for the role of cyclooxygenase (COX)-2 inhibitors in the patients of depression. A web based search was done using the keywords like antidepressants, anti-inflammatory treatment, celecoxib, depression, neuro inflammation in well recognized databases like PubMed, Google scholar from the year 2006 to 2019 to come out with data that matches our inclusion criteria that have been pooled and critically analyzed. Although the exact mechanism remains to become elucidated the results suggest that COX-2 have beneficial role in treatment of depression and it may be used as an adjunct to the antidepressant treatment as it may hasten the response to current treatment without any serious side effects.
\end{abstract}

Keywords: Depression, COX-2 inhibitors, Inflammation, Major depressive disorder, Celecoxib

\section{INTRODUCTION}

Major depressive disorder is the most commonly diagnosed psychiatric disorder and predicted to be the most common cause of disability by the year $2020 .{ }^{1}$ The response rates of the currents medications available in the market for the treatment of depression is very low which cause the researchers to study about the other pathologies involved in depression. One of this pathology is the link of immune system and depression. Decreased responsiveness to the conventional anti-depressant treatment increases the need to study about the other pathologies involved in depression. There is extensive evidence present in the literature that links the etiopathogenesis of depression to the immune system. Several studies had been conducted worldwide that suggests that psychological stress has an important effect on the immune system and found that components of immune system such as interleukin (IL)-1 $\beta$, IL-6, soluble IL-2 receptors and tumour necrosis factor-alpha (TNF- $\alpha$ ) were elevated in depressive patients. ${ }^{2}$ However the reason of association between the immune system and depression is still not clear and there is a commodious scope of research in this field.

The purpose of doing this review is to study the effect of anti-inflammatory treatment in the patients of depression 
in adjunct to their regular treatment regime or to the nonresponder cases. The term inflammation describes the immune related processes in the body which can either be acute or chronic when it persists for several years. During peripheral inflammatory response many proinflammatory cytokines such as TNF- $\alpha$ or IL-6, are produced by the body which communicate with other cells of the immune systems like B cells and T cells. Central inflammatory response is mediated by microglia which is the most immunocompetent cell in the brain. Microglia secretes neurotrophic factors which are responsible for recruiting immune cells into the CNS and for cellular repair. ${ }^{3}$ Smith et al first described the relationship between inflammatory cytokines and depression based on observation of cytokines produced by the macrophages after giving them to healthy volunteer which then induce depressive symptoms in the volunteers. ${ }^{4}$ Another study conducted by in this field which unfolded the immunological activation in the patients of depression and the other study demonstrated that in response to infection and inflammatory conditions, peripherally produced cytokines can act on the central nervous system and produce behavioural symptoms like malaise, fatigue, numbness and anorexia., ${ }^{5,6}$ Since inflammation is involved in pathophysiology of depression this review was to look for the studies showing effect of COX-2 inhibitors in the patients diagnosed with depression. COX-2 is the cytokine inducible enzyme which is expressed in inflammatory cells and is responsible for the prostaglandin production in the inflammatory processes. ${ }^{2}$ The beneficial effect of COX-2 inhibitors in improving cognition in the patients of schizophrenia is already been studied. ${ }^{7}$ A preclinical study had shown higher serotonin levels in the rats brain after administration of rofecoxib, a COX-2 inhibitor. ${ }^{8}$ Another animal study showed that chronic administration of celecoxib decreased cytokine levels and changed the animal behavior. Thus the authors hypothesized the role of COX-2 inhibitors in depression. ${ }^{9}$

\section{METHODS}

The study consisted of the narrative review based on the web based search performed in the well-recognised databases like PubMed, Google scholar. Search was conducted to include the articles from 2006 to 2019. The following inclusion and exclusion criteria were defined to refine the search and select the articles.

\section{Inclusion criteria}

Clinical studies conducted to compare COX-2 inhibitors with conventional anti-depressants and with no other serious medical condition were included in this study.

\section{Exclusion criteria}

Preclinical studies as well as clinical studies in patients having some other disorders along with depression were excluded from the study.

\section{RESULTS}

Our search yielded 11 articles in which the clinical study was performed to assess the efficacy of COX-2 inhibitors in depression. 3 studied were excluded as they have some major pathology along with depression in which study one study included the patients of colorectal cancer having depression, one assessing the efficacy of celecoxib in patients of breast cancer with depression and one with the patients of brucellosis with depression. ${ }^{10-12}$ These studies were excluded as these simultaneous diseases can affect the results.

Table 1: Articles included in our study.

\begin{tabular}{|c|c|c|c|c|c|c|}
\hline Study & Year & Diagnosis & $\begin{array}{l}\text { No. of } \\
\text { patients }\end{array}$ & Duration & Drug & Results \\
\hline Muller et al ${ }^{13}$ & 2006 & $\begin{array}{l}\text { Acute } \\
\text { depressive } \\
\text { episode }\end{array}$ & 40 & 6 weeks & $\begin{array}{l}\text { Reboxetine }+ \\
\text { celecoxib, reboxetine }+ \\
\text { placebo }\end{array}$ & $\begin{array}{l}\text { Reboxetine }+ \text { celecoxib is } \\
\text { superior than reboxetine }+ \\
\text { placebo }\end{array}$ \\
\hline Nary et al ${ }^{19}$ & 2008 & $\begin{array}{l}\text { Bipolar } \\
\text { disorder }\end{array}$ & 28 & 6 weeks & $\begin{array}{l}\text { Current treatment }+ \\
\text { celecoxib, current } \\
\text { treatment }+ \text { placebo }\end{array}$ & $\begin{array}{l}\text { Current treatment }+ \\
\text { celecoxib is superior than } \\
\text { current treatment }+ \text { placebo }\end{array}$ \\
\hline $\begin{array}{l}\text { Akhodazadeh } \\
\text { et } \mathbf{a l}^{14}\end{array}$ & 2009 & MDD & 40 & 6 weeks & $\begin{array}{l}\text { Fluoxetine + celecoxib, } \\
\text { fluoxetine + placebo }\end{array}$ & $\begin{array}{l}\text { Fluoxetine }+ \text { celecoxib is } \\
\text { superior than fluoxetine }+ \\
\text { placebo }\end{array}$ \\
\hline Abbasi et al ${ }^{16}$ & 2012 & MDD & 40 & 6 weeks & $\begin{array}{l}\text { Sertraline + celecoxib, } \\
\text { sertraline + placebo }\end{array}$ & $\begin{array}{l}\text { Sertraline }+ \text { celecoxib is } \\
\text { superior than sertraline }+ \\
\text { placebo }\end{array}$ \\
\hline Majid et al ${ }^{15}$ & 2015 & MDD & 30 & 4 weeks & $\begin{array}{l}\text { Sertraline + celecoxib, } \\
\text { sertraline + placebo }\end{array}$ & $\begin{array}{l}\text { Sertraline }+ \text { celecoxib is } \\
\text { superior than sertraline }+ \\
\text { placebo }\end{array}$ \\
\hline Krause et al ${ }^{18}$ & 2017 & MDD & 40 & 6 weeks & $\begin{array}{l}\text { Reboxetine }+ \\
\text { celecoxib, reboxetine }+ \\
\text { placebo }\end{array}$ & $\begin{array}{l}\text { Reboxetine }+ \text { celecoxib is } \\
\text { superior than reboxetine }+ \\
\text { placebo }\end{array}$ \\
\hline
\end{tabular}




\begin{tabular}{|c|c|c|c|c|c|c|}
\hline Study & Year & Diagnosis & $\begin{array}{l}\text { No. of } \\
\text { patients }\end{array}$ & Duration & Drug & Results \\
\hline Fourier et $\mathrm{al}^{20}$ & 2018 & MDD & 200 & 6 weeks & $\begin{array}{l}\text { Vortioxetine }+ \\
\text { celecoxib, vortioxetine } \\
+ \text { placebo }\end{array}$ & $\begin{array}{l}\text { Vortioxetine }+ \text { celecoxib is } \\
\text { superior than vortioxetine }+ \\
\text { placebo }\end{array}$ \\
\hline Castillo et al ${ }^{17}$ & 2019 & $\begin{array}{l}\text { Treatment } \\
\text { resistant } \\
\text { MDD }\end{array}$ & 70 & 12 weeks & $\begin{array}{l}\text { Escitalopram } \\
\text { + celecoxib, } \\
\text { escitalopram } \\
\text { + placebo }\end{array}$ & $\begin{array}{l}\text { Escitalopram } \\
+ \text { celecoxib is superior than } \\
\text { escitalopram } \\
+ \text { placebo }\end{array}$ \\
\hline
\end{tabular}

Thus we included 8 studies in our narrative review which are summarised in Table 1. A double blinded randomised controlled trial conducted with 40 patients that were randomly assigned to reboxetine plus placebo, or reboxetine plus celecoxib group showed the superiority of celecoxib plus reboxetine group with increased scores in Hamilton depression scale $(\mathrm{p}=0.035) .{ }^{13}$ Other clinical trials also showed the similar results with combining fluoxetine and sertraline with celecoxib and comparing them to placebo group. ${ }^{14,15}$ One randomised controlled trial on 40 patients receiving either celecoxib or placebo in addition to sertraline had shown reduction in serum IL6 concentration along with Hamilton scores and showed a significant correlation between the two parameters $(\mathrm{p}<0.001)$ at 8 weeks. ${ }^{16}$ The other study included the 70 treatment resistant patients of bipolar disorder to look for the efficacy of adding celecoxib with escitalopram and comparing it to placebo found the symptomatic improvement in the celecoxib group after 12 weeks. They also demonstrated the reduced quinolinic acid in the treatment group but this reduction was not statistically significant. ${ }^{17}$ One study also demonstrated the significant lowering of kynurenine levels in the treated group $(\mathrm{p}=0.008)$ and significantly increased kynurenine or tryptophan ratio in the celecoxib group $(\mathrm{p}=0.028)$. The lowering of kynurenine is associated with better outcomes in the patient of depression. ${ }^{18}$ The studies which monitored the side effects of celecoxib during the course of study reported no significant risk in the celecoxib group and no major cardiovascular events or gastro intestinal problems. ${ }^{14,15,19}$ The dose of celecoxib taken was $200-400 \mathrm{mg} /$ day.

\section{DISCUSSION}

The web based search of the literature on the use of COX-2 inhibitors in depression as per our inclusion criteria yielded 8 articles from the year 2006 to 2019 . These articles showed the beneficial effects of celecoxib as an add on treatment to their previous medication in the cases of major depression. No study was found as per our search in which only celecoxib was prescribed to the patients without adding any conventional anti-depressant medication. At the site of inflammation COX-2 is produced and responsible for the synthesis of prostaglandins. ${ }^{21}$ The beneficial effect of celecoxib can be related to its inflammatory property and involvement of inflammation in depression. The most studied mechanism which links inflammation to depression is the increased cytokines in depression which stimulate indole dioxygenase enzyme that inhibits the conversion of tryptophan to serotonin which is important neurotransmitter involved in the pathophysiology of depression and directs this pathway to the formation of other metabolites like quinolinic acid which exerts neurotoxicity and also involved in neurodegeneration. ${ }^{1}$ The increase in quinolinic acid is also showed by one study included in our review and demonstrated the correlation of increase in quinolinic acid with symptoms of depression. ${ }^{17} \mathrm{COX}-2$ inhibitors inhibit the synthesis of PGE2 by inhibiting COX enzyme. PGE2 reduces the release of noradrenaline from central noradrenergic neurons. ${ }^{14}$ Thus COX-2 inhibitors can increase both serotonergic and nor adrenergic neurotransmission. The animal study has reported that celecoxib reduces blood PGE2, IL-1beta, and corticosterone concentrations and increasing nerve growth factor expression in experimental rats. ${ }^{22}$

Celecoxib can also prevent dysregulation of the Hypothalamic-pituitary-adrenal (HPA) axis and glucocorticoid receptor function possibly through reduction in PGE2 and IL-6 production. ${ }^{23}$ It has been suggested that abnormalities in the HPA axis might play a key role in the development and recurrence of depression. ${ }^{24}$ No serious side effects were reported in any of the study included in our review. The dose of celecoxib used was 200-400 mg/day. This result can also be supported by the meta-analysis conducted to determine the safety and efficacy of celecoxib in the patients of osteoarthritis that concluded that celecoxib can be used in the dose of $200 \mathrm{mg} /$ day with acceptable adverse effects for $10-14$ weeks. ${ }^{25}$

\section{CONCLUSION}

COX-2 inhibitors could be used as an add on medication in the treatment resistant patients of depression in the low doses. However more research is required in this area to study about the long term safety of COX-2 inhibitors. Further studies are also required to know about the exact mechanism of the beneficial role of COX-2 inhibitors in depression.

\section{Funding: No funding sources Conflict of interest: None declared Ethical approval: Not required}




\section{REFERENCES}

1. Feltes KP, Doorduin J, Klein HC, Juárez-Orozco LE, Dierckx RA, Moriguchi-Jeckel CM, et al. Antiinflammatory treatment for major depressive disorder: implications for patients with an elevated immune profile and non-responders to standard antidepressant therapy. J Psychopharmacol. 2017;31(9):1149-65.

2. Hughes MM, Connor TJ, Harkin A. Stress-related immune markers in depression: implications for treatment. Int J Neuropsychopharmacol. 2016;19(6).

3. Rawdin BJ, Mellon SH, Dhabhar FS, Epel ES, Puterman E, Su Y, et al. Dysregulated relationship of inflammation and oxidative stress in major depression. Brain Behav Immun. 2013;31:143-52.

4. Smith RS. The macrophage theory of depression. Med Hypotheses. 1991;35(4):298-306.

5. Maes M, Bosmans E, De Jongh R, Kenis G, Vandoolaeghe E, Neels H. Increased serum IL-6 and IL-1 receptor antagonist concentrations in major depression and treatment resistant depression. Cytokine. 1997;9(11):853-8.

6. Dantzer R, Bluthe RM, Gheusi G, Cremona S, Laye $\mathrm{S}$, Parnet $\mathrm{P}$, et al. Molecular basis of sickness behavior. Ann New York Acad Sci. 1998;856(1):132-8.

7. Muller N, Riedel M, Schwarz MJ, Engel RR. Clinical effects of COX-2 inhibitors on cognition in schizophrenia. Europ Arch Psychiatr Clin Neurosci. 2005;255(2):149-51.

8. Sandrini M, Vitale G, Pini LA. Effect of rofecoxib on nociception and the serotonin system in the rat brain. Inflammation Res. 2002;51(3):154-9.

9. Myint AM, Kim YK, Verkerk R, Scharpe S, Steinbusch H, Leonard B. Kynurenine pathway in major depression: evidence of impaired neuroprotection. J Affect Disorder. 2007;98(1):14351.

10. Alamdarsaravi M, Ghajar A, Noorbala AA, Arbabi M, Emami A, Shahei F, et al. Efficacy and safety of celecoxib monotherapy for mild to moderate depression in patients with colorectal cancer: a randomized double-blind, placebo controlled trial. Psychiatr Res. 2017;255:59-65.

11. Mohammadinejad P, Arya P, Esfandbod M, Kaviani A, Najafi M, Kashani L, et al. Celecoxib versus diclofenac in mild to moderate depression management among breast cancer patients: A doubleblind, placebo-controlled, randomized trial. Ann Pharmacotherap. 2015;49(9):953-61.

12. Jafari S, Ashrafizadeh SG, Zeinoddini A, Rasoulinejad M, Entezari P, Seddighi S, et al. Celecoxib for the treatment of mild-to-moderate depression due to acute brucellosis: a double-blind, placebo-controlled, randomized trial. J Clin Pharm Therapeut. 2015;40(4):441-6.

13. Muller N, Schwarz MJ, Dehning S, Douhe A, Cerovecki A, Goldstein-Muller B, et al. The cyclooxygenase- 2 inhibitor celecoxib has therapeutic effects in major depression: results of a double-blind, randomized, placebo controlled, add-on pilot study to reboxetine. Molecular Psychiatr. 2006;11(7):680.

14. Akhondzadeh S, Jafari S, Raisi F, Nasehi AA, Ghoreishi A, Salehi B, et al. Clinical trial of adjunctive celecoxib treatment in patients with major depression: a double blind and placebo controlled trial. Depression Anxiety. 2009;26(7):607-11.

15. Majd M, Hashemian F, Hosseini SM, Shariatpanahi MV, Sharifi A. A randomized, double-blind, placebocontrolled trial of celecoxib augmentation of sertraline in treatment of drug-naive depressed women: a pilot study. Iran J Pharmaceut Res. 2015;14(3):891.

16. Abbasi SH, Hosseini F, Modabbernia A, Ashrafi M, Akhondzadeh S. Effect of celecoxib add-on treatment on symptoms and serum IL-6 concentrations in patients with major depressive disorder: randomized double-blind placebo-controlled study. J Affect Disorder. 2012;141(2-3):308-14.

17. Castillo MF, Murata S, Schwarz M, Schutze G, Moll $\mathrm{N}$, Martin B, et al. Celecoxib augmentation of escitalopram in treatment-resistant bipolar depression and the effects on quinolinic acid. Neurol Psychiatr Brain Res. 2019;32:22-9.

18. Krause D, Myint AM, Schuett C, Musil R, Dehning $\mathrm{S}$, Cerovecki A, et al. High kynurenine (a tryptophan metabolite) predicts remission in patients with major depression to add-on treatment with celecoxib. Frontiers Psychiatr. 2017;8:16.

19. Nery FG, Monkul ES, Hatch JP, Fonseca M, ZuntaSoares GB, Frey BN, et al. Celecoxib as an adjunct in the treatment of depressive or mixed episodes of bipolar disorder: a double-blind, randomized, placebo-controlled study. Hum Psychopharmacol: Clin Exp. 2008;23(2):87-94.

20. Fourrier C, Sampson E, Mills NT, Baune BT. Antiinflammatory treatment of depression: study protocol for a randomised controlled trial of vortioxetine augmented with celecoxib or placebo. Trials. 2018;19(1):447.

21. Seibert K, Zhang Y, Leahy K, Hauser S, Masferrer J, Perkins $\mathrm{W}$, et al. Pharmacological and biochemical demonstration of the role of cyclooxygenase 2 in inflammation and pain. Proceedings Natl Acad Sci. 1994;91(25):12013-7.

22. Song $C$, Zhang XY, Manku M. Increased phospholipase A2 activity and inflammatory response but decreased nerve growth factor expression in the olfactory bulbectomized rat model of depression: effects of chronic ethyl-eicosapentaenoate treatment. J Neurosci. 2009;29(1):14-22.

23. Casolini P, Catalani A, Zuena AR, Angelucci L. Inhibition of COX-2 reduces the age-dependent increase of hippocampal inflammatory markers, corticosterone secretion, and behavioral impairments in the rat. J Neurosci Res. 2002;68(3):337-43.

24. Wohhleb ES, Hanke ML, Corona AW, Powell ND, La'Tonia MS, Bailey MT, et al. $\beta$-Adrenergic receptor antagonism prevents anxiety-like behavior 
and microglial reactivity induced by repeated social defeat. J Neurosci. 2011;31(17):6277-88.

25. Xu C, Gu K, Yasen Y, Hou Y. Efficacy and safety of celecoxib therapy in osteoarthritis: a meta-analysis of randomized controlled trials. Med (Baltimore). 2016;95(20):e3585.
Cite this article as: Abbas A, Kumar N, Choudhary $\mathrm{R}$. The use of cyclooxygenase- 2 inhibitors in depression: a narrative review of the state of evidence. Int J Basic Clin Pharmacol 2019;8:234953. 